\title{
Pengembangan Produk dan Pemasaran Usaha Noga Kelapa Guna Meningkatkan Pendapatan Masyarakat Kampung Mekarjaya Desa Padamulya
}

\section{Product Development and Marketing Of Coconut Noga Busuness In Order to Increase The Income of Mekarjaya Village Padamulya}

\author{
Trisnawati ${ }^{1}$ \\ ${ }^{1}$ Program Studi Ekonomi Syariah Fakultas Ekonomi Islam Universitas Djuanda Bogor, Jl Tol Ciawi No.1, \\ Kotak Pos 35 Bogor 16720, e-mail: ranggaardiansyah028@gmail.com
}

(Diterima: 25-06-2020; Ditelaah: 25-09-2020; Disetujui: 10-02-2021)

\begin{abstract}
Abstrak
Sumber Daya Alam yang dihasilkan Desa Padamulya sangat melimpah, akan tetapi sumber daya alam yang dimiliki Desa Padamulya belum sepenuhnya dimanfaatkan oleh masyarakatnya, sehingga perlu adanya bimbingan atau pendampingan kepada masyarakat untuk memanfaatkan potensi yang ada. Salah satunya dengan memanfaatkan produk olahan singkong yang dibuat menjadi sebuah makanan dengan harga nilai jual tinggi. Metode yang dilakukan adalah dengan sosialisasi dan pembuatan inovasi produk olahan kelapa. Dalam pengolahan produk olahan singkong ini penulis membuat noga kelapa yang merupakan makanan cemilan enak dan sehat. Setelah dilaksanakan program ini hasil yang didapatkan adalah pengembangan produk olahan kelapa lebih kreatif dan inovatif serta masyarakat sekitar lebih memahami cara memanfaatkan sebuah potensi yang ada di sekitar.
\end{abstract}

Kata Kunci: Inovasi Produk, Kelapa, Pengabdian Masyarakat

\begin{abstract}
The natural resources produced by Padamulya Village are very abundant, but the natural resources owned by Padamulya Village have not been fully utilized by the community, so there is a need for guidance or assistance to the community to exploit the existing potential. One of them is by utilizing processed cassava products that are made into food with high selling price. The method used is the socialization and innovation of coconut products. In processing this cassava product, the writer makes coconut nogawhich is a delicious and healthy snack food. After implementing this program the results obtained are the development of coconut processed products more creative and innovative as well as the surrounding community better understanding how to utilize a potential that is around.
\end{abstract}

Keywords: Coconut, Community Service, Product Innovation

\section{PENDAHULUAN}

Pengabdian mahasiswa kepada masyarakat dilaksanakan untuk memenuhi salah satu tri dharma perguruan tinggi, yakni pengabdian kepada masyarakat yang bersifat lintas disiplin dan sebagai komponen keilmuan, teknologi dan seni secara aplikatif guna membentuk kehidupan masyarakat, utamanya di pedesaan. Bentuk pengabdian tersebut dilaksanakan dengan cara menerapkan ilmu pengetahuan yang sudah diperoleh di perkuliahan kepada masyarakat. Ilmu pengetahuan yang diterapkan adalah ilmu pengetahuan yang diperlukan oleh masyarakat atau yang dapat menjadi solusi bagi permasalahan yang terjadi kehidupan masyarakat. Hal ini dilakukan sebagai wujud rasa 
kepedulian dan tanggung jawab mahasiswa untuk memajukan bangsa dan negara di masa depan (Lubis, 2004).

Peningkatan perekonomian adalah suatu perubahan jenjang atau perbaikan kondisi dari perekonomian yang lemah kearah perekonomian yang lebih baik atau mengalami kemajuan dari sebelumnya. Pengembangan ekonomi lokal perlu diarahkan untuk mendukung perkembangan sektor- sektor ekonomi yang mempunyai potensi menciptakan kesempatan kerja yang luas dan memiliki prospek yang baik dalam meningkatkan kesejahteraan masyarakat di suatu wilayah. Maka dari itu dengan adanya program ekonomi kreatif yang dilakukan diharapkan mampu merubah sedikit demi sedikit perekonomian masyarakat yang ada di Desa Padamulya dengan mengadakan inovasi baru untuk menjadikan kampung tersebut memiliki mata pencaharian yang lebih beragam dengan memanfaatkan barang bekas yang nantinya dapat bernliai seni dan bernilai jual atau bernilai ekonomis.

Inovasi dalam konteks birokrasi diamanatkan dalam Undang-undang menjadi salah satu pendorong untuk percepatan pembangunan, hal ini sudah terbukti dengan model yang diterapkan di negara maju. Dewasa ini, peningkatan produktivitas tidak hanya bergantung pada pada ilmu pengetahuan dan teknologi melainkan pada ketersediaan sumber daya alam yang dimiliki. Pengembangan kewirausahaan menduduki peran yang sangat strategis makin signifikan. Kita harus mendorong dan mengembangkan kemampuan wirausaha, memanfaatkan peluang bisnis dalam dinamika persaingan global (Prasetyo, 2018).

Tumbuhnya industri kreatif di Indonesia disebabkan adanya krisis global yang berkepanjangan sehingga memunculkan semangat yang lebih dalam menciptakan, mengkreasikan, dan menginovasikan sesuatu dalam menciptakan ide-ide dan karya-karya yang baru. Arief Johari menyatakan bahwa pertumbuhan industri kreatif yang baik di Indonesia belum mampu memberikan pengaruh yang positif dan signifikan bagi Indonesia salah satu penyebabnya adalah "Manajemen Problem" yaitu suatu pemikiran yang menyebabkan adanya pemikiran bahwa sebuah produk yang dihasilkan hanya untuk konsumsi di dalam negeri sehingga hal inilah menyebabkan bahwa Indonesia termasuk pada kategorisasi sebagai negara konsumtif yang potensial secara internasiona. Berdasarkan uraian di atas maka perumusan masalah adalah ekonomi kreatif sebagai suatu solusi mensejahterakan masyarakat dalam meningkatkan tingkat perekonomian.

Dalam hal ini sebuah inovasi sangat diperlukan untuk bisa menciptakan ekonomi kreatif yang di inginkan. Adapun yang dimaksud dengan inovasi adalah sebuah gagasan, produk atau proses yang memiliki potensi untuk digunkan sebagai pemacu daya saing sebuah bangsa, wilayah, industri, organisasi, indivisu atau gabungan dari katagori- katagori ini.

Kelapa(cocos nucifera) merupakan makanan pokok ketiga setelah padi dan jagung bagi masyarakat Indonesia. Tanaman ini dapat tumbuh sepanjang tahun di daerah tropis dan memiliki daya adaptasi yang tinggi terhadap kondisi berbagai tanah. Tanaman ini 
memiliki kandungan gizi yang cukup lengkap. Kelapa merupakan salah satu tanaman lokal unggulan Indonesia. Pada beberapa wilayah, kelapa menjadi tanaman yang dominan di pekarangan. Selain itu, pada tanaman padi sebagian petani menumpangsarikan salah satunya yaitu tanaman kelapa (Iskandar dkk., 2016). Selama ini pengolahan kelapa sebatas pembuatan produk makanan intstan yaitu dengan kelapa muda. Untuk variasi pengolahan belum banyak diketahui oleh masyarakat umum khususnya ibu-ibu rumah tangga. Sehingga pelaksanaan kegiatan pengabdian ini bertujuan memberikan informasi dan keterampilan baru dalam proses pengolahan kelapa khususnya kepada ibu-ibu rumah tangga.

Desa padamulya adalah desa yang berada dipegunungan dengan kualitas tanah yang subur. Masyarakat kebanyakan adalah seorang petani yang menanam pohon kelapa, hasil pertanian tersebut sangat melimpah akan tetapi masyarakat hanya memanfaatkan buah kelapa tersebut sebatas dimakan yang mudanya dan santan tanpa inovasi. Jika dapat dikelola dengan baik dan kreatif, kelapa tersebut akan menjadi suatu inovasi baru yang memberikan nilai ekonomi bagi masyarakat.

Sumber Daya Alam yang dihasilkan Desa Padamulya sangat melimpah, akan tetapi sumber daya alam yang dimiliki Desa Padamulya belum sepenuhnya dimanfaatkan oleh masyarakatnya, sehingga perlu adanya bimbingan atau pendampingan kepada masyarakat untuk memanfaatkan potensi yang ada. Salah satunya dengan memanfaatkan produk olahan kelapa yang dibuat menjadi sebuah makanan dengan harga nilai jual tinggi. Pemilihan program pemanfaatan olahan kelapa ini dilakukan karna melihat potensi kelapa yang melimpah akan tetapi harga nilai jual kelapa tersebut sangat rendah.

\section{METODE PELAKSANAAN}

Metode pelaksanaan yang dilakukan penulis berupa pendampingan ekonomi masyarakat dengan cara membentuk kelompok usaha yang akan mengembangkan potensi sumber daya alam yang ada disekitar wilayah desa Padamulya dengan membuat sebuah inovasi produk olahan kelapa. Adapun lokasi yang dijadikan tempat pelaksanaannya adalah Desa Padamulya, Kecamatan Pasirkuda, Kabupaten Cianjur, Provinsi Jawa Barat. Alasan dipilih Desa Padamulya sebagai karena kategori desa tersebut merupakan desa tertinggal, sehingga memerlukan banyak bantuan untuk mengembangkannya, terutama bantuan Sumber Daya Manusia (SDM) untuk mengembangkan potensi-potensi desa tersebut.

\section{HASIL \& PEMBAHASAN}

Berikut tahap pelaksanaan program pendampingan dan pembuatan produk olahan kelapa. 
Tahap Memahami Permasalahan

Dalam tahap ini penulis memahami permasalahan dengan melakukan survei kepada masyarakat sekitar Kp. Mekarjaya Desa Padamulya dalam rangka melakukan identifikasi masalah yang ada. Sehingga penulis dapat merencanakan solusi untuk mengatasi masalah tersebut. Setelah melakukan identifikasi ditemukan bahwa permasalahan yang ada di Desa Padamulya adalah kurangnya pemanfaatan potensi seumber daya dehingga diperlukan pendampingan untuk meningkatkan potensi tersebut.

Tahap Membuat Solusi

Dalam tahap membuat solusi terbagi menjadi beberapa tahap diantaranya:

a) Survei Potensi Sumber Daya Alam (SDA)

Survei lokasi dilakukan di wilayah Kp. Mekarjaya RT 08 RW 02 Desa Padamulya. Pelaksanaan survei dilakukan dengan cara melihat potensi tanaman kelapa yang melimpah dan berada disetiap lahan, kemudian mencari tahu kebiasaan masyarakat dalam memanfaatkan kelapa tersebut. Selain itu penulis juga melakukan survei dengan bertanya kepada masyarakat yang memiliki kelapa dirumahnya, kebanyakan masyarakat Mekarjaya memiliki kelapa akan tetapi pengolahannya hanya begitu saja.

Hasil dari survei yang sudah dilakukan ialah, banyaknya kelapa yang ada dikampung tersebut, namun tidak di manfaatkan dengan baik. Masyarakat memanfaatkan kelapa hanya dengan di, di jadikan santan, pembuatan kue kering namun tidak untuk dijual atau diolah menjadi produk yang mempunyai nilai jual tinggi. Harga kelapa pun tidak terlalu tinggi, mencapai kisaran harga 1 buah Rp. 3.000.-saja, sehingga masyarakat tidak terlalu memanfaatkan kelapa tersebut hanya dibagikan pada warga lain untuk diberikan secara cuma- cuma. Kemudian munculah ide pembuatan noga kelapa dengan tujuan untuk menaikkan harga jual kelapa dan gula aren tersebut melalui inovasi produk.

b) Pengembangan Inovasi Produk

Berdasarkan hasil survei yang dilakukan oleh tim pelaksana, banyak pohon kelapa yang ada di wilayah Padamulya tersebut. Untuk meminimalisir terjadinya kegagalan dalam pembuatan produk maka penulis melakukan percobaan dan pengembangan produk kelapa tersebut. Percobaan pembuatan noga kelapa ini dilakukan dua kali hingga menemukan hasil yang sempurna dan sesuai dengan apa yang diinginkan.

Selama masa percobaan pembuatan dihasilkan komposisi yang pas dalam pembuatan produk noga kelapa yaitu 1/5 kg kelapa yang sudah di parut, 1/5 kg gura aren, setengah sendok makan gula, 1 sihung jahe dan 1 sendok minyak. Dengan komposisi yang pas ini produk yang dihasilkan memiliki tekstur rasa tidak terlalu manis.

c) Membuat Desain Logo dan Kemasan

Ketika percobaan pembuatan produk berhasil, langkah selanjutnya adalah membuat desain logo dan kemasan yang dilakukan oleh penulis. Pembuatan desain kemasan dibuat dengan semenarik mungkin agar menarik perhatian konsumen. Dalam pemasaran produk, pembuatan nama yang menarik sangat penting untuk produk yang akan 
disebarluaskan di jangkauan kecil, menengah dan besar. Langkah pembuatan desain produk meliputi:

1) Penulis menggunakan aplikasi canva untuk membuat desain logo produk

2) Mencari membuat skema gambar kelapa dan gula yang menarik dengan cara pengeditan aplikasi.

3) Menentukan format penulisan, font, size dan warna.

4) Mencantumkan logo yang sudah jadi di gambarkan.

Berikut Logo kemasan produk noga kelapa.

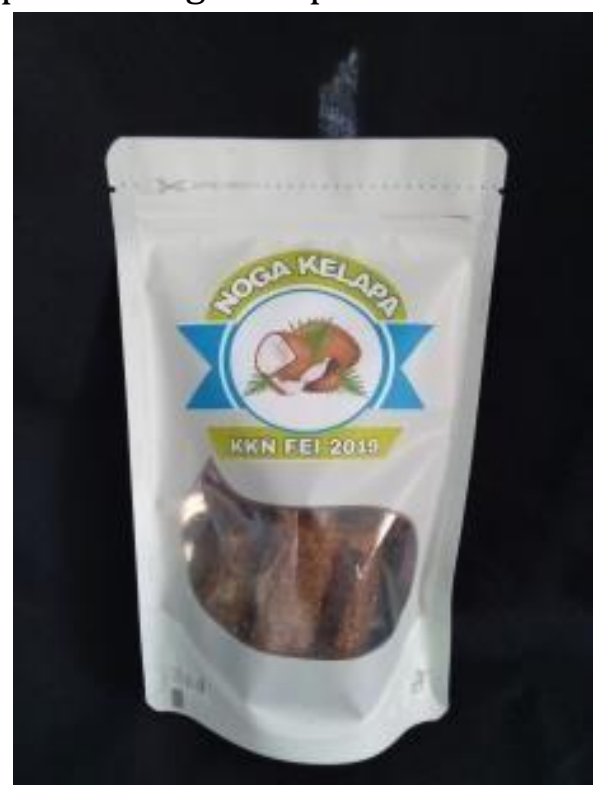

Gambar 1. Kemasan Noga Kelapa

d) Pembelian Bahan Kebutuhan Produk

Penulis menyediakan kemasan produk yang sudah dibuat kemudian menyiapkan bahan-bahan untuk pembuatan noga kelapa. Bahan-bahannya antara lain kelapa, gula aren, garam,jahe dan minyak.

e) Memberikan Informasi Kepada Masyarakat

Setelah melakukan survei lokasi, percobaan atau pengembangan produk dan membuat desain kemasan, penulis melakukan koordinasi dengan tokoh masyarakat setempat bahwa ada produk inovasi baru yang akan di sosialisasikan untuk masyarakat banyak. Kemudian meminta izin untuk mengadakan sosialisasi terkait produk yang sudah dipersiapkan. Perizinan dilakukan kepada tokoh di kampung Mekarjaya. Pengumuman kepada masyarakat dilakukan 3 hari sebelum pelaksanaan praktik pembuatan produk setelah melakukan perizinan.

Tahap Melaksanakan Solusi

Dalam melaksanakan solusi dilakukan dengan Pelatihan produk pembuaatan noga kelapa dilaksanakan pada tanggal 22 Agustus 2019 dan 29 Agustus 2019. Pelatihan produksi produk ini dihadiri oleh ibu-ibu kelompok 6. Produksi pembuatan noga kelapa dilakukan dengan beberapa tahap seperti proses pengupasan, proses pencucian, proses 
meraut, proses nyangrai, proses pelelhan gula, proses penggabungan kelapa dan gula aren hingga proses pengemasan. Berikut proses pengolahan noga kelapa:

1) Tahap pertama, proses pengupasan kulit dan pemarutan kelapa

2) Tahap kedua, prosesmenyangrai kelap hingga kecoklatan, selanjutnya jika kelapa sudah berubah warna menjadi kecoklatan lalu angkat.

3) Tahap ketiga, lelehkan gula aren hingga meleleh dan jangan sampai mendidih, lalu masukan kelapa yang sudah di sangrai ke dalam lelehan gula dan aduk hingga merata.

4) Tahap ke empat, cetak adonan yang tadi sesuai dengan keinginan kita.

5) Produk siap di kemasan dan pemasaran

\section{KESIMPULAN}

Perekonomian masyarakat Desa Padamulya masih perlu untuk ditingkatkan. Walaupun perekonomian masyarakat Desa Padamulya masih dapat dikatakan standar, tetapi tingkat perekonomian Desa Padamulya tersebut dapat ditingkatkan melalui kegiatan ekonomi kreatig melalui inovasi produk. Dapat dilihat dari segi geografis kampung Goleah berada pada kawasan yang stategis dikelilingi oleh beberapa wisata seperti Curug Citambur, dan Wisata Pohon Pinus. Hal ini dapat dimanfaatkan untuk menggali potensi masyarakat di bidang ekonomi dan dengan adanya kegiatan pelatihan inovasi produk olahan kelapa ini diharapkan dapat menjadi wadah bagi masyarakat untuk bisa memasarkannya sebagai sebuah oleh- oleh atau buah tangan khas Desa Padamulya.

Setelah mengikuti kegiatan pelatihan pembuatan inovasi produk olahan kelapa para ibu rumah tangga diharapkan bisa mencari celah bisnis yang ada dan dapat mengembangkannya sendiri di rumah masing-masing.

\section{DAFTAR PUSTAKA}

Aldy Purnomo, Rochmat. 2016. Ekonomi Kreatif Pilar Pembangunan Indonesia. Surakarta: Ziyad Visi Media.

Hamali, Sambudi. (2016). Pengaruh Inovasi Terhadap Kinerja Bisnis Pada Industri Kecil Pakaian Jadi Kota Bandung.

Prasetyo, A. (2018). Potensi Peningkatan Produktivitas Kewirausahaan Berbasis Model Penguatan Teknopreneur pada Hasil Inovasi KotaMagelang. 